\title{
Qualitative ultrastructural analysis of the submandibular salivary glands after administration of khat: in vivo study
}

\author{
Gamilah Al-Qadhi ${ }^{*}$ (1) and Rabab Mubarak ${ }^{2}$
}

\begin{abstract}
Objective: Khat (Catha edulis Forssk) plant has been widely chewed for its psychostimulatory effects in the African and Arabian Peninsula, particularly in Yemen. Considering the khat leaves are gradually chewed without swallowing, while its active constituents are extracted into saliva, studying the effect of khat on salivary glands is necessary. This work is an extension of the previously published work that studied the effect of khat extract on the rats' submandibular salivary glands in terms of histological and immunohistochemical evaluations. The current research note aimed to better understand this effect on the ultrastructure of submandibular salivary gland cells by using transmission electron microscope.

Results: Oral administration of khat extract produced degenerative changes in the secretory and ductal cells of rats' submandibular salivary glands. These changes involved irregular boundaries of variable sized-nuclei, dilated RER, cytoplasmic vacuoles as well as swollen and degenerated mitochondria.
\end{abstract}

Keywords: Khat, Catha edulis, Submandibular salivary gland, Ultrastructural changes, TEM

\section{Introduction}

Khat or qat (Catha edulis Forssk) is a type of plant known for its psychostimulatory effects. Khat chewing is a common bad social habit among African and Arabian people, particularly Yemeni ones. People gradually chew khat for several hours every day and kept the khat bolus inside the lower buccal vestibule to make a characteristic swelling on one side of the cheek. Later on, the leaves are spit out and the obtained juice is swollen [1,2].

The active constitutes of khat, including (-) cathinone, which has a similar pharmacological picture as amphetamine, and cathine [3]. Various studies have demonstrated the negative effects of khat on body, such as the cardiovascular system $[4,5]$, the central nervous system $[6,7]$,

\footnotetext{
*Correspondence: gamilah.alqadhi@dentistry.cu.edu.eg

${ }^{1}$ Department of Basic Dental Sciences, Faculty of Dentistry, University

of Science and Technology, Taiz, Yemen

Full list of author information is available at the end of the article
}

neonatal, maternal health $[8,9]$, fertility $[10,11]$, cellular toxicity, apoptosis in human cells [12-14], structural chromosomal aberrations [15], and increased production of reactive oxygen species (ROS) [16].

An association between khat chewing and oral lesions has been illustrated in several articles, including white lesions, periodontal diseases, and tooth discoloration, where they were significantly more prevalent in the khat chewers than non-chewers [17-20]. More importantly, prolonged exposure to the khat may be a contributing factor for the high incidence of oral squamous carcinoma [21].

Saliva has a critical role in the preservation and maintenance of oral health and dental integrity. Dysfunction of saliva occurs as a sequence of a certain disease or as a side effect of several drugs or even as a result of bad habits [22]. Oral dryness was reported in khat chewers 30 min after the beginning of the khat-chewing session [20].

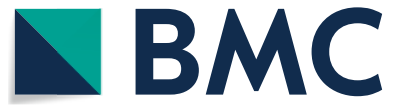

(c) The Author(s) 2021. This article is licensed under a Creative Commons Attribution 4.0 International License, which permits use, sharing, adaptation, distribution and reproduction in any medium or format, as long as you give appropriate credit to the original author(s) and the source, provide a link to the Creative Commons licence, and indicate if changes were made. The images or other third party material in this article are included in the article's Creative Commons licence, unless indicated otherwise in a credit line to the material. If material is not included in the article's Creative Commons licence and your intended use is not permitted by statutory regulation or exceeds the permitted use, you will need to obtain permission directly from the copyright holder. To view a copy of this licence, visit http://creativeco mmons.org/licenses/by/4.0/. The Creative Commons Public Domain Dedication waiver (http://creativecommons.org/publicdomain/ zero/1.0/) applies to the data made available in this article, unless otherwise stated in a credit line to the data. 
Similarly, decreased salivary parameters such as the flow rate and $\mathrm{pH}$ were observed among khat chewers and this condition might be related to the amphetamine-like effect of khat or continuous mechanical action of the salivary glands during the chewing session [23]. Histological analysis showed signs of atrophied acini and degenerated ductal cells in rat's salivary glands treated by khat [24]. It should be mentioned that this research note is considered as an extension of that previous work [24], which was published in a local college journal, and aimed to better understand the effects of khat extract on the submandibular salivary glands in terms of ultrastructural profile.

\section{Main text}

\section{Materials and methods}

\section{Experimental design}

Rats are reliable models to study the salivary glands as they have considerable morphological and histological similarities with the human one [25]. Healthy adult male Albino Wistar rats (species: Rattus Norvegicus) $(\mathrm{n}=20)$ of average weight $150 \pm 10 \mathrm{~g}$ and 3-4 months old were used in this study. The rats were obtained from and housed in the animal house at the Institute of Ophthalmology, Cairo University under the control of a specialized veterinarian. All animals were kept under the same housing and feeding conditions (12-12 h light/dark cycle, $25 \pm 2{ }^{\circ} \mathrm{C}$ room temperature, and $50 \pm 5 \%$ relative humidity).

They were housed in a specially designed filter-top polypropylene cages $(48.5 \mathrm{~cm} \mathrm{~L} \times 33 \mathrm{~cm} \mathrm{~W} \times 21 \mathrm{~cm} \mathrm{H})$. The cages were cleaned twice weekly, bedded with woodchips, and supplied with cardboard boxes, and fleece chew toy for environmental enrichment. They were fed with the standard laboratory rat diet (Meladco Feed Co., Cairo, Egypt) and water ad libitum. The experiment was conducted after one week of acclimatization of animals to their new environment in the research room.

Each rat was matched with a specific number (from 1 to 20 ) by the technician at the animal house and randomly divided into two groups (10 rats/group) using the randomizer website. Sample size calculation was carried out using resources equation method as the current study didn't have any quantitative data, so 10 and 20 rats can be considered as an adequate sample, in which $\mathrm{E}$ measured by following formula: $\mathrm{E}=$ total number of animals - total number of groups [26].

The control group received $1 \mathrm{ml}$ of normal saline, and the khat-treated group received $1000 \mathrm{mg} / \mathrm{kg}$ b.w $(=1 \mathrm{ml})$ of aqueous khat extract twice a week (Monday and Thursday) for ten consecutive weeks via a sterile oral gavage flexible polyurethane-feeding tube. The dose was considered as a medium dose and selected according to previous reports $[15,27]$. Among different types of khat, the Nehmi khat leaves had the highest concentration of cathinone and tannic acid [28]. Therefore, they were used to extract the desired dose following the previous work [29].

\section{Transmission electron microscopy (TEM)}

After ten weeks of the experiment, the animals were euthanized by an overdose of sodium pentobarbital (intraperitoneal injection) $100 \mathrm{mg} / \mathrm{kg}$ (Anapental 1, Pharma Tech, Egypt). Following the standard technique [30], the submandibular salivary glands were dissected free, cleaned rapidly from any adherent connective tissues and prepared for the TEM ${ }^{1}$ examination to detect cellular ultrastructural changes of salivary glands.

\section{Results}

All rats survived during the experimental period without any complications.

\section{The secretory portion}

The submandibular salivary glands of the control group revealed the ultrastructure elements of their constituent tissues. The serous secretory cells showed large spherical opened-faced nuclei with electron-dense prominent nucleoli. Parallel cisternae of the rough endoplasmic reticulum (RER) were located basal and lateral to the nucleus. The apical cytoplasm was filled with numerous small membrane-bounded secretory granules of variable electron densities (Fig. 1a).

The khat-treated group revealed moderate changes, such as dilated cisternae of RER and disfigured mitochondria, large number of secretory granules of variable sizes and electron densities. Also, numerous coalescent electron-lucent cytoplasmic vacuoles of variable sizes and densities were observed (Fig. 1b). The nuclei showed some decrease in size with an irregularly delineated nuclear membrane (Fig. 1c). 

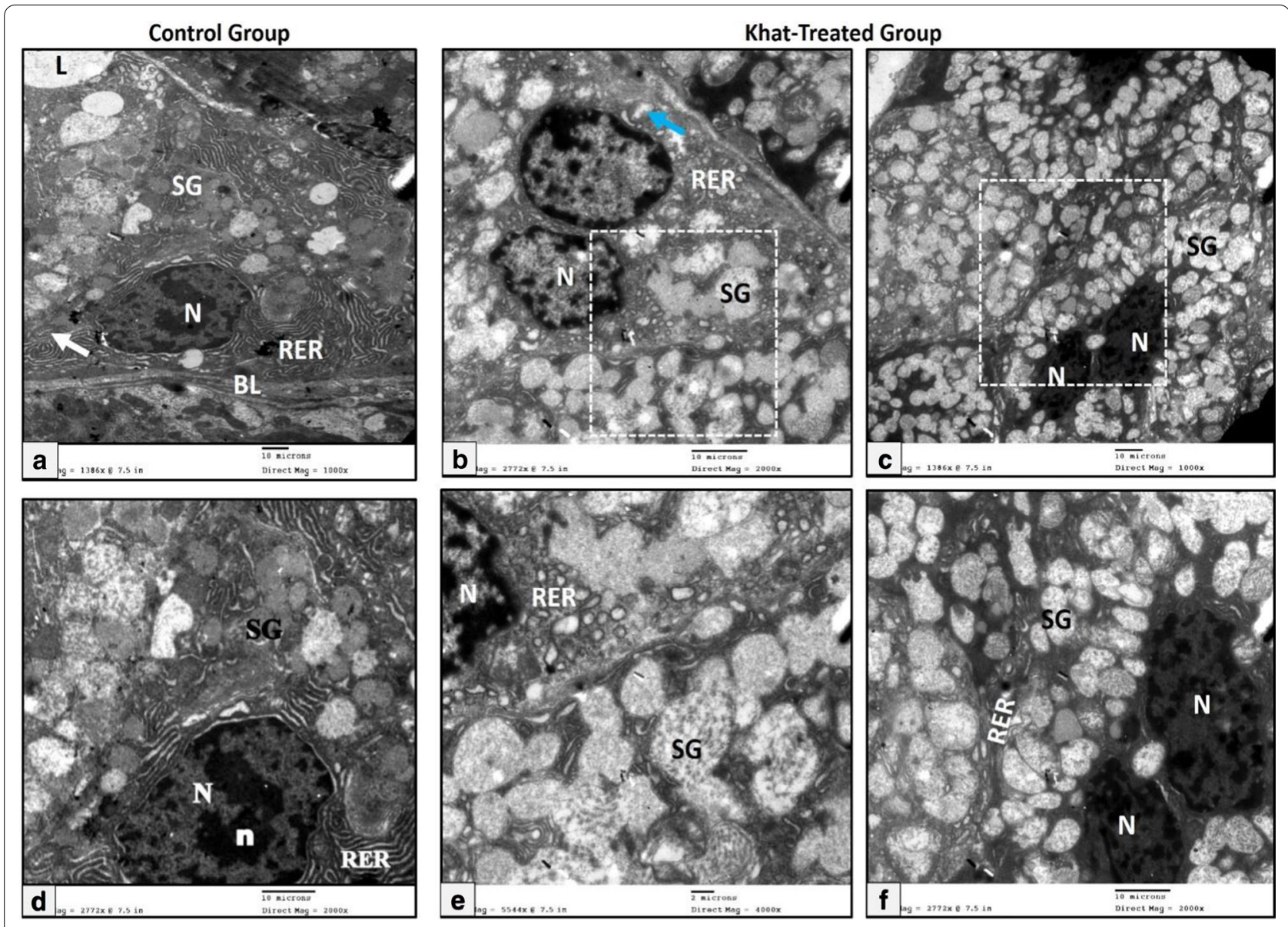

Fig. 1 Electron micrographs of the serous cells of the rat submandibular salivary gland showing (a) control group: open-faced nucleus (N), well developed rough endoplasmic reticulum (RER), mitochondria (white arrow), basal lamina (BL), variable sized membrane-bounded secretory granules (SG) and lumen (L), b, c khat-treated group: numerous coalescent electron lucent secretory granules (SG), nucleus with irregular nuclear membrane (N), dilated cisternae of rough endoplasmic reticulum (RER) and swollen mitochondria with degenerated internal cristae (blue arrows) (Uranyl acetate \& lead citrate X 1000), d-f A higher magnification of the squared dotted area (Uranyl acetate \& lead citrate X 2000) (Scale bar: $10 \mu \mathrm{m}$ )

\section{Duct system}

Control striated duct cells showed round central openfaced nuclei. The cells were characterized by deep infoldings of their basal plasma membrane, which contained numerous vertically arranged mitochondria arranged parallel to the long axis of the cell. (Fig. 2a). In the khat-treated group, the mitochondria were the most affected cellular organelles in the duct system. They appeared reduced in number and degenerated with loss of the normal architecture of their cristae.
The striated ducts showed evident signs of degeneration manifested as a decrease of the basal infoldings associated with markedly swollen and degenerating mitochondria (Fig. 2b, c). Three fields per image were selected randomly and subjected to analysis using cell counter command in the Image software (National Institute of Health (NIH), USA). The results revealed that the average number of damaged mitochondria in the khat-treated group was $7.166 \pm 5.49$ per field in comparison with the control group $0.766 \pm 0.727$. 

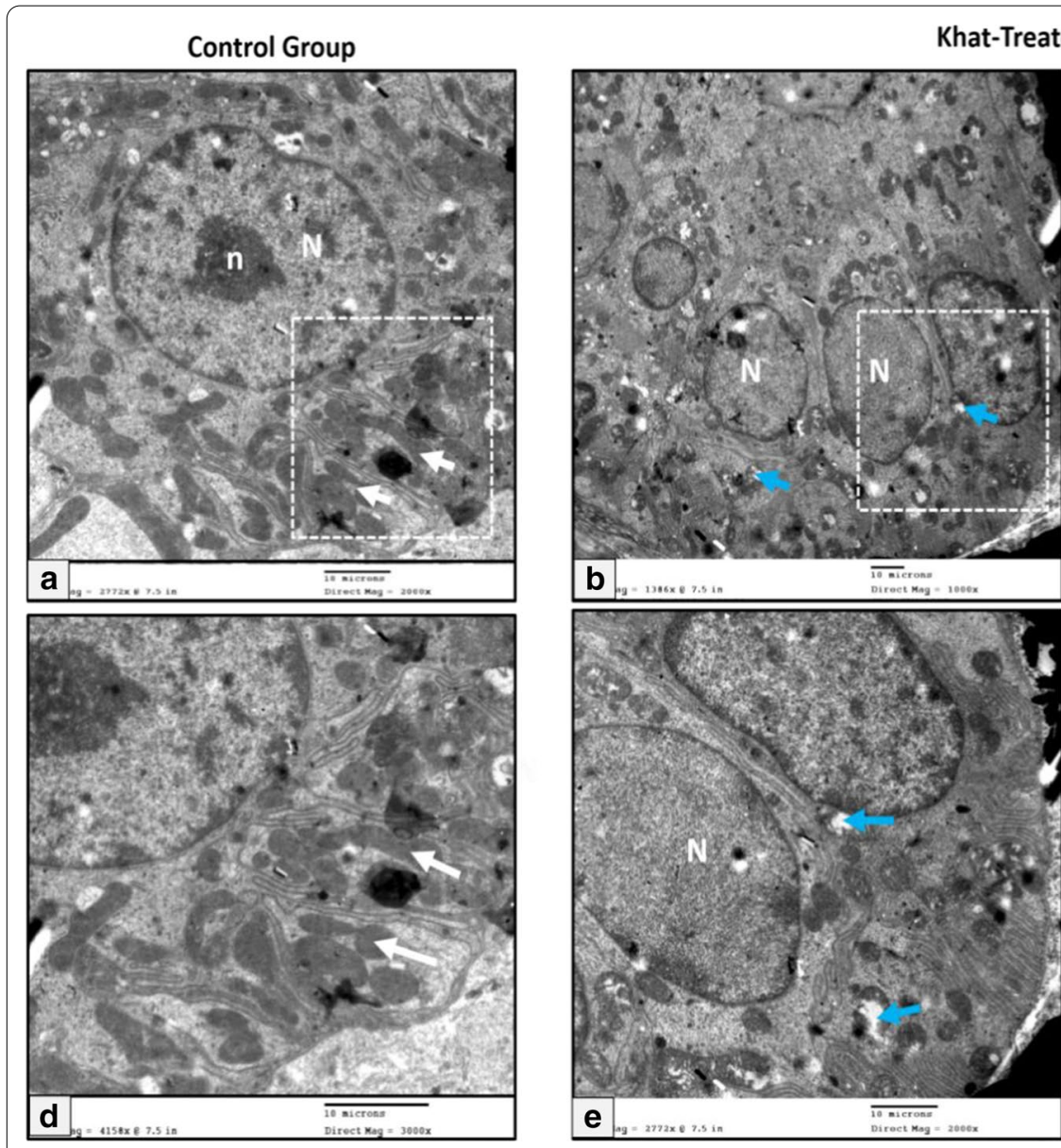

\section{ed Group}
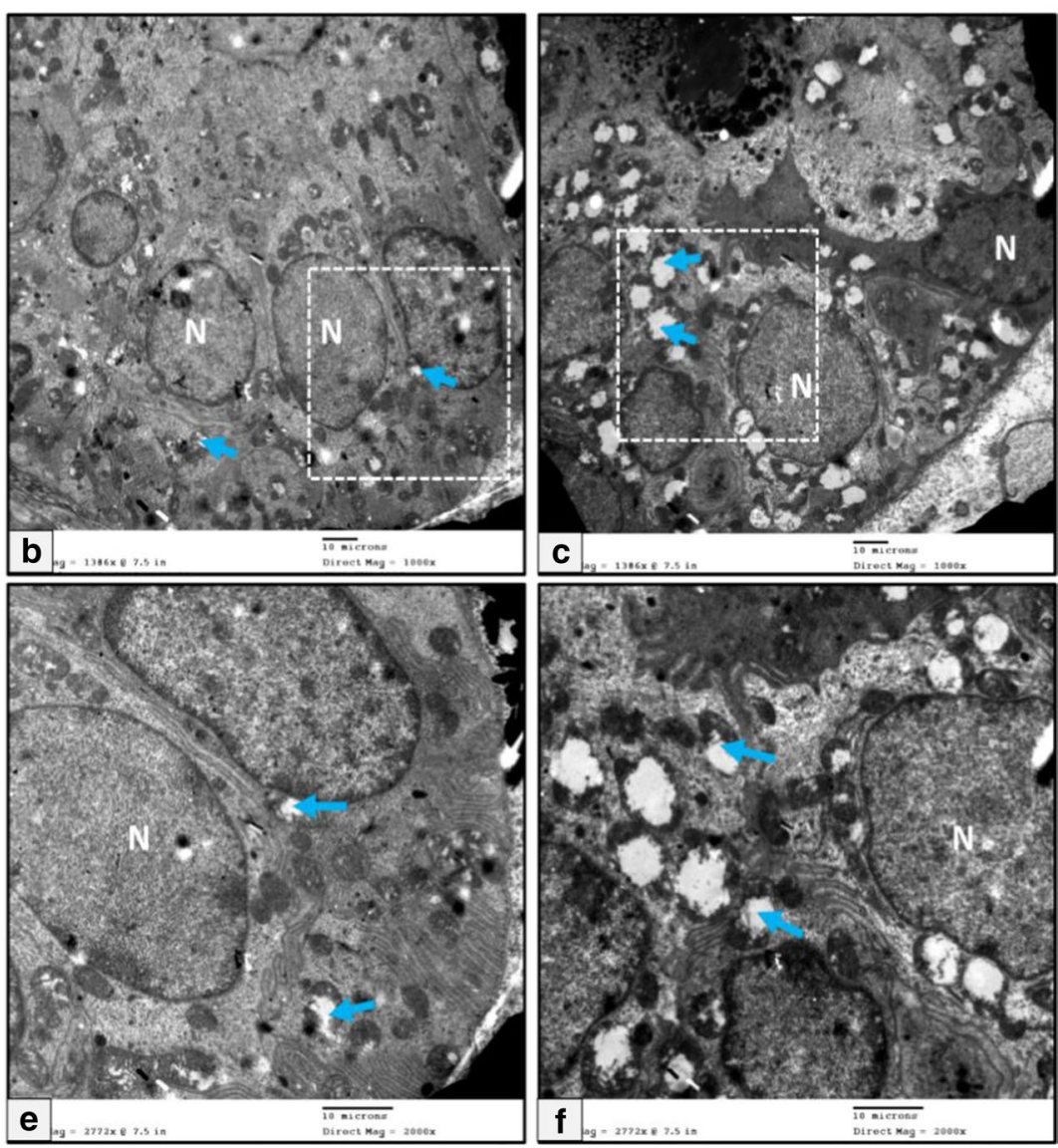

Fig. 2 Electron micrographs of the striated duct showing (a) control group; characteristic infolded basal membrane containing abundant mitochondria (white arrows), central nucleus (N) with prominent nucleolus (n), b, c khat- treated group of the submandibular and the sublingual salivary glands respectively; nuclei with variable sizes $(\mathrm{N})$ and basal folding contained degenerated mitochondria (blue arrows) (Uranyl acetate \& lead citrate X 1000), $\mathbf{d}-\mathbf{f}$ higher magnification of the squared dotted area (Uranyl acetate \& lead citrate X 2000) (Scale bar: 10 $\mu \mathrm{m}$ )

The submandibular salivary glands of the rat were characterized by a special type of duct called granular convoluted tubules. The apical part of the cytoplasm of the tall columnar cells of those ducts contained well circumscribed membrane-bounded electrondense secretory granules. Their open-faced nuclei were located in the basal part of the cells (Fig. 3a). However, the granular convoluted duct cells had wide lumen cast with multiple large electron-lucent secretory materials. In addition to deformed mitochondria, accumulation of electron-lucent secretory material beside the characteristic electron-dense granules of the granular convoluted ducts were observed in the khat-treated group (Fig. 3b, c).

\section{Connective tissue stroma}

The connective tissue stroma showed collagen fibers, fibroblasts, and blood vessels lined by endothelial cells and filled with electron-dense corpuscle. In addition to the inflammatory cells and fibroblasts, dilated thickwalled blood vessels engorged with electron-dense RBCs were observed in the khat-treated group (See Additional file 1).

\section{Discussion}

Khat produced side effects on the general and oral health of khat chewers as reviewed earlier. This study indicates that Khat extract adversely affected the submandibular salivary glands to different degrees in terms of 

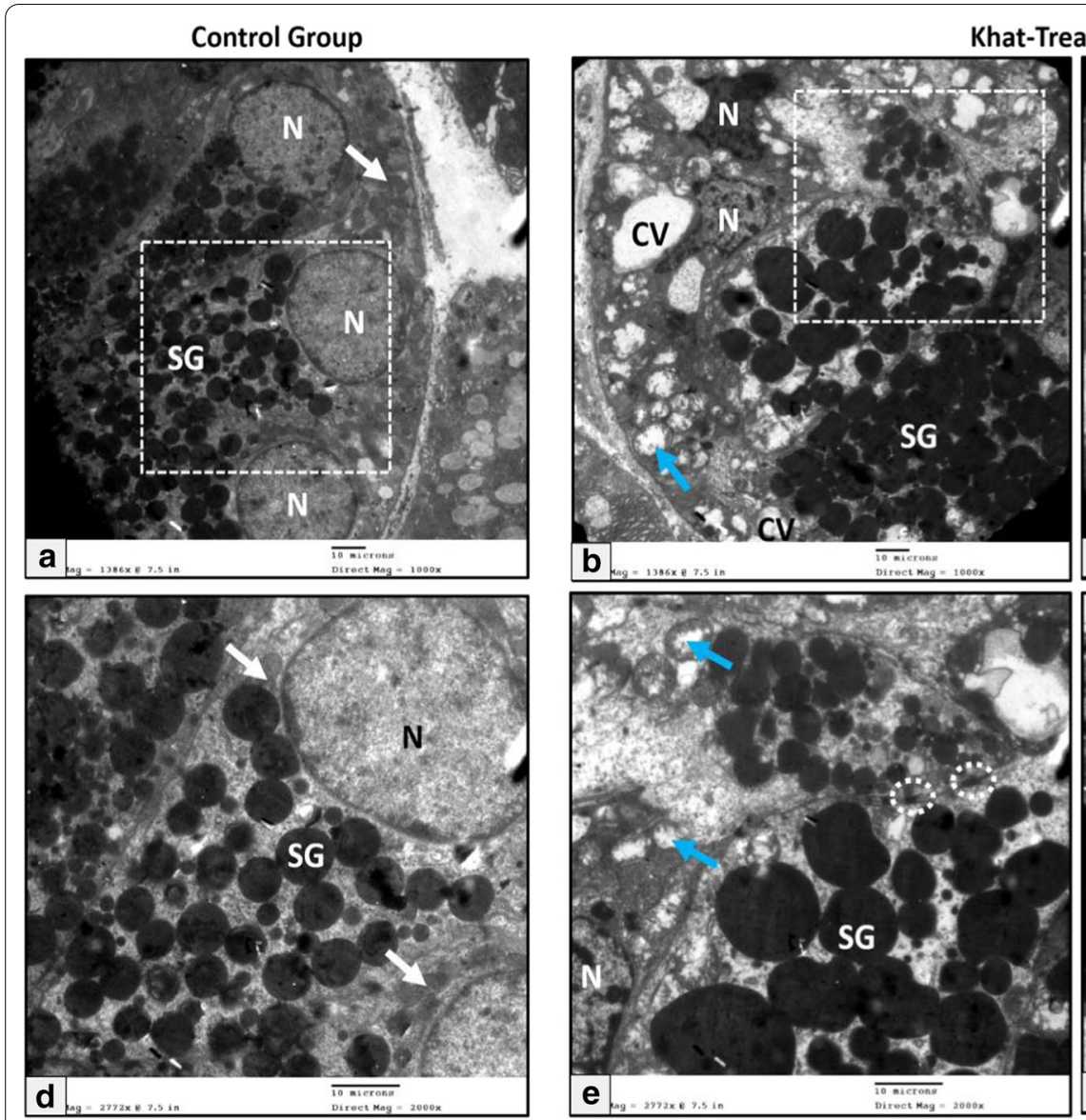

\section{ated Group}
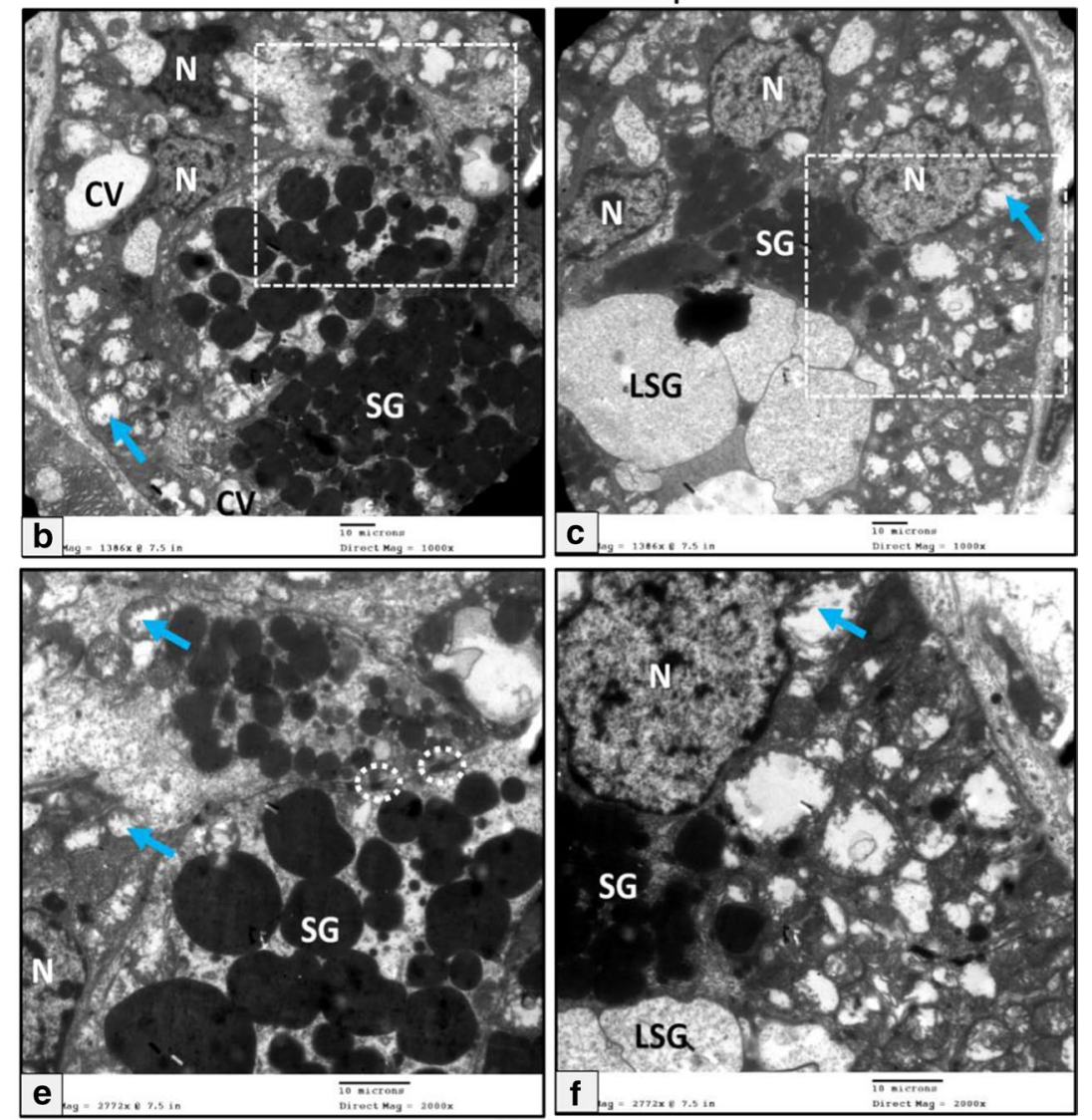

Fig. 3 Electron micrographs of the granular convoluted tubules of the rat submandibular salivary gland showing (a) control group: basally situated nuclei (N), supranuclearlocalization of numerous electron dense secretory granules of different sizes (SG), mitochondria (white arrows), b, $\mathbf{c}$ khat-treated group: deformed basally situated nuclei (N), electron dense secretory granules (SG), accumulation of electron lucent secretory material (LSG), cytoplasmic vacuoles of variable sizes (CV), degenerated mitochondria (blue arrows) and desmosome junctions between cells (dotted circles) (Uranyl acetate \& lead citrate X 1000), d-f higher magnification of the squared dotted area (Uranyl acetate \& lead citrate X 2000) (Scale bar: $10 \mu \mathrm{m}$ )

ultrastructure evaluation. The dryness of the mouth was the major complaint during and after khat chewing and there was an obvious effect of khat on salivary flow rate after khat chewing [23]. To overcome this problem, the chewers usually drink a considerable amount of water or mineral juices during chewing session. This situation might be due to sympathomimetic effects of the active component of khat (cathinone) or due to over-secretion of saliva during the continuous chewing. The salivary dysfunction was in accordance with signs of degeneration observed in this study.

The nuclei of secretory cells exhibited variation in shape and size "pleomorphism", chromatin changes and irregularity of the nuclear membrane. These changes may be due to the decreased metabolic activity and reduction in protein synthesis due to the toxic effect of khat. Along the same line, a molecular-based comparison indicated that khat chewers had a significantly higher micronuclei frequency than non-chewers [31]. Micronucleus frequency in the exfoliated buccal cells exhibited deformed nucleus (irregular in shape and had loops) seen only in khat chewers and smokers group [32]. This might be indicative of aberrations at the cellular level. In accordance with the current findings, the khat extract induced significant morphological changes in human acute myeloid leukemia cells such as cell shrinkage, segregation of intracellular organelles, the formation of membrane blebs or buds, the appearance 
of cytoplasmic vacuoles, disruption of the nuclear membrane, and condensation and fragmentation of nuclear chromatin [33].

Both secretory and duct cells showed degenerated mitochondria, which occur as a consequence of impairment of metabolic process and are considered as an indication of decreased activity of the duct cells. These changes can be explained by the presence of (-) cathinone, the active compound of khat, that causes damage in the cell membrane integrity, a decline in adenosine triphosphate (ATP levels), and increased mitochondrial superoxide concentrations [34].To some extent, these results were compatible with a study conducted by Lukandu et al. [35], Khat-exposed human oral keratinocytes and fibroblasts showed a swift and sustained decrease of the mitochondrial inner transmembrane potential and associated with a significant decrease in cell survival.

Similarly, Khat produced inner mitochondrial membrane damage, cristae degradation, chromatin condensation, and morphological features of autophagy. Numerous RER showed dilated cisternae, which might be a sign of cell injury rather than a sign of increased secretory activity. The expansion of RER maybe an indicator of disturbances in the exocytosis process of the secretory material or occur as a form of reversible cell injury, leading to the accumulation of secretory materials inside cisternae [36].

Khat treated groups exhibited dilated blood vessels studded with blood corpuscles and other blood vessels showed swollen endothelial lining that caused the collapse of their lumen and obstruction of blood flow. These findings were consistent with the congestion of the central hepatic vein, hypertrophied glomerular capillaries and dilated Bowman's capsule of kidney demonstrated in animals treated with khat, which may be induced by lowfrequency stimulation of cathinone [37, 38]. Overall, the khat extract induced moderate ultrastructure changes in the submandibular salivary glands.

\section{Conclusion}

Oral administration of khat extract produced a range of cellular degenerative alterations in the rats' submandibular salivary glands, including irregular nuclear membrane, mitochondria degeneration and cytoplasmic vacuoles.

\section{Limitations}

This study has a potential limitation in terms of lacking the flow rate assessment. Moreover, further studies are required to determine the molecular profile associated with these changes. In particular, the expression of genes responsible for regulating saliva secretion.

\section{Supplementary Information}

The online version contains supplementary material available at https://doi. org/10.1186/s13104-021-05595-8.

Additional file 1: Figure S1. A photograph shows the leaves of khat. Figure S2. Transmission electron microscopy images of the mucous cells showing (a) control group: open-faced nucleus (N), rough endoplasmic reticulum (RER), numerous electron lucent secretory granules (Mucin granules) (SG) and basal lamina (BL), (b, c) khat-treated group: nuclei with irregular nuclear membrane ( $\mathrm{N}$ ), dilated cisternae of rough endoplasmic reticulum (RER), swollen degenerated mitochondria (blue arrow), cytoplasmic vacuoles of variable sizes (CV) and secretory granules with disrupted membrane or fused electron lucent material replacing cell cytoplasm (SG) (Uranyl acetate \& lead citrate X 1000), (d,e,f) A higher magnification of the squared dotted area (Uranyl acetate \& lead citrate X 2000) (Scale bar: $10 \mu \mathrm{m}$ ). Figure S3. Transmission electron microscopy images of the connective tissue septa (a,b) control group: blood vessel (BV), fibroblast ( $F$ ), cross-banding of collagen fibers (CF), (c-f) khat- treated group: thick walled blood vessel with electron dense RBCs (BV), lymphocyte $(L)$ and fibroblast (F) (Uranyl acetate \& lead citrate X 2000) (Scale bar: $10 \mu \mathrm{m}$ ).

\section{Acknowledgements}

Not applicable.

\section{Authors' contributions}

GA designed, conducted the laboratory steps, analyzed, interpreted the results, and was a major contributor in writing the manuscript. RM supervised the work, contributed to the study design, and provided the laboratory support. Both authors read and approved the final manuscript.

\section{Funding}

This research did not receive any specific grant from funding agencies in the public, commercial, or not-for-profit sectors.

\section{Availability of data and materials}

All data generated or analysed during this study are included in this published article.

\section{Declarations}

Ethics approval and consent to participate

The study was approved from the research ethics committees, Faculty of

Dentistry, Cairo University in accordance with ARRIVE guideline [39].

Consent for publication

Not applicable.

Competing interests

The authors declare that they have no competing interests. 


\section{Author details}

${ }^{1}$ Department of Basic Dental Sciences, Faculty of Dentistry, University of Science and Technology, Taiz, Yemen. ${ }^{2}$ Department of Oral Biology, Faculty of Dentistry, Cairo University, Cairo 11553, Egypt.

Received: 24 December 2020 Accepted: 5 May 2021

Published online: 13 May 2021

\section{References}

1. Patel NB. Mechanism of action of cathinone: the active ingredient of khat (catha edulis). East Afr Med J. 2000;77(6):329-32.

2. Dhaifalah I, SantavY J. Khat habit and its health effect: a natural amphetamine. Biomed Pap. 2004;148(1):11-5.

3. Szendrei K. The chemistry of khat. Bull Narc. 1980;32(3):5-35.

4. Abdel-kader ZY. The effect of Qat chewing on blood pressure and heart rate in healthy volunteers. Trop Doct. 2000;30:107-8.

5. Al-motarreb A, Al-habori M, Broadley KJ. Khat chewing, cardiovascular diseases and other internal medical problems : The current situation and directions for future research. J Ethnopharmacol. 2010;132(3):540-8.

6. Kalix P. The pharmacology of khat. Gen Pharma. 1984;15(3):179-87.

7. Hassan N, Gunaid A, El Khally F, Murray-Lyon I. The subjective effects of chewing qat leaves in human volunteers. Ann Saudi Med. 2002;22(1-2):34-7.

8. Hassen K. Khat (Catha edulis) chewing as a risk factor of low birth weight among full term Newborns: a systematic review. World Fam Med J. 2015;13(7):1-5.

9. Abdel-Aleem A, Al-aghbari A, Mustafa M, Nasr AA, Assad A. Khat chewing during pregnancy: an insight on an ancient problem. Impact of chewing Khat on maternal and fetal outcome among Yemeni pregnant women. J Gynecol Neonatal Biol. 2015;1(2):28-31.

10. Tariq M, Qureshi S, Ageel AM, Al-meshal LA. The induction of dominant lethal mutations upon chronic administration of khat (Catha edulis ) in albino mice. Toxicol Lett. 1990;50(2-3):349-53.

11. Nyachieo A, Kiraithe MM, Spiessens C, Chai DC, Kiulia NM, Hooghe TMD, et al. Short-term effects of high-dose Khat on sperm parameters and reproductive hormonal levels in Olive Baboons (Papio anubis ). Gynecol Obs Invest. 2013;75:109-14.

12. Lukandu OM, Costea DE, Neppelberg E, Johannessen AC, Vintermyr OK. Khat (Catha edulis) induces reactive oxygen species and apoptosis in normal human oral keratinocytes and fibroblasts. Toxicol Sci. 2008;103(2):311-24.

13. Mohan S, Abdelwahab SI, Hobani YH, Syam S, Al-zubairi A, Alsanosy R, et al. Catha edulis extract induces $\mathrm{H} 9 \mathrm{c} 2$ cell apoptosis by increasing reactive oxygen species generation and activation of mitochondrial proteins. Pharmacogn Mag. 2016;12(Suppl 3):1-13.

14. Abdelwahab SI, Alsanosy R, Mohamed M, Taha E, Mohan S. Khat induced toxicity: role on its modulating effects on inflammation and oxidative stability. Biomed Res Int. 2018;2018:1-7.

15. Al-zubairi A, Ismail P, Pei C, Rahmat A. Genotoxic effect of Catha edulis ( khat ) crude extract after sub-chronic administration in rats. Environ Toxicol Pharmacol. 2008:25:298-303.

16. Al-qirim TM, Shahwan M, Zaidi KR, Uddin Q, Banu N. Effect of khat, its constituents and restraint stress on free radical metabolism of rats. J Ethnopharmacol. 2002;83:245-50.

17. Ali A, Al-Sharabi A, Aguirre J, Nahas R. A study of 342 oral keratotic white lesions induced by qat chewing among 2500 Yemeni. J Oral Pathol Med. 2004;33(6):368-72.

18. Schmidt-Westhausen A, Al Sanabani J, Al-Sharabi A. Prevalence of oral white lesions due to qat chewing among women in Yemen. Oral Dis. 2014:20(7):675-81.

19. Al-Maweri S, Warnakulasuriya S, Samran A. Khat (Catha edulis) and its oral health effects: an updated review. J Investig Clin Dent. 2018;9(1):1-9.
20. Yarom N, Epstein J, Levi H, Porat D, Kaufman E, Gorsky M. Oral manifestations of habitual khat chewing: a case-control study. Oral Surgery Oral Med Oral Pathol Oral Radiol Endodontol. 2010;109(6):e60-6.

21. Sawair FA, Al-Mutwakel A, Al-Eryani K, Al-Surhy A, Maruyama S, Cheng J, et al. High relative frequency of oral squamous cell carcinoma in Yemen: qat and tobacco chewing as its aetiological background. Int J Environ Health Res. 2007:17(3):185-95.

22. Humphrey SP, Williamson RT. A review of saliva: Normal composition, flow, and function. J Prosthet Dent. 2001:85(2):162-9.

23. Al-alimi KR, Aziz A, Razak A. Salivary caries parameters : Comparative study among Yemeni khat chewers and nonchewers. J Dent Sci. 2014;9(4):328-31.

24. Al-Qadhi G, Mubarak R, El-motayam A. Effects of khat extract on the submandibular salivary glands of Albino rats (histological and immunohistochemical study). Egypt Dent J. 2012;58(1):273-83.

25. Roa I, Del Sol M. Parotid gland comparative microscopic anatomy. Int J Morphol. 2019;37(2):701-5.

26. Charan J, Kantharia N. How to calculate sample size in animal studies ? Pharmacol Pharmacother. 2013;4(4):129-32.

27. Alsalahi A, Abdulla MA, Al-mamary M, Noordin MI, Abdelwahab SI, Alabsi AM, et al. Toxicological features of Catha edulis ( Khat) on livers and kidneys of male and female sprague-dawley rats : a subchronic study. Evidence-Based Compl Altern Med. 2012;2012:1-11.

28. Al-motarreb A, Baker K, Broadley KJ. Khat: Pharmacological and medical aspects and its social use in Yemen. Phytother Res. 2002;16:403-13.

29. Nyongesa AW, Patel NB, Onyango DW, Odongo HO, Wango EO. Khat (Catha edulis) lowers plasma luteinizing hormone $(\mathrm{LH})$ and testosterone secretion, but increases cortisol levels in male rabbits. J Ethnopharmacol. 2008;116(2):245-50.

30. Hayat MA. Basic Techniques for Transmission Electron Microscopy. 1st editio. Academic press. New York: Harcourt Brace Jovanovich; 1986.

31. Kassie F, Darroudi F, Kundi M, Schulte-Hermann R, Knasmüller S. Khat (Catha edulis) consumption causes genotoxic effects in humans. Int J Cancer. 2001;92(3):329-32.

32. Saleh K. Synergistic effect of catha edulis and smoking on exfoliated cells in south west region of Saudi Arabia (Asser). Acta Pharm Sci. 2010:52:453-60.

33. Dimba E, Gjertsen B, Bredholt T, Fossan K, Costea D, Francis G, et al. Khat ( Catha edulis )-induced apoptosis is inhibited by antagonists of caspase-1 and -8 in human leukaemia cells. Br J Cancer. 2004;91:1726-34.

34. Zhou X, Luethi D, Sanvee GM, Bouitbir J, Liechti ME, Krähenbühl S. Molecular toxicological mechanisms of synthetic cathinones on c2c12 myoblasts. Int J Mol Sci. 2019:20(7):1561.

35. Lukandu OM, Bredholt T, Neppelberg E, Gjertsen BT, Johannessen AC, Vintermyr OK, et al. Early loss of mitochondrial inner transmembrane potential in khat-induced cell death of primary normal human oral cells. Toxicology. 2009;263:108-16.

36. Bredholt T, Dimba E, Hagland H, Wergeland L, Skavland J, Fossan K, et al. Camptothecin and khat (Catha edulis Forsk.) induced distinct cell death phenotypes involving modulation of c-FLIPL, Mcl-1, procaspase-8 and mitochondrial function in acute myeloid leukemia cell lines. Mol Cancer. 2009;8:1-13.

37. Al-Mamary M, Al-Habori M, Al-Aghbari AM, Baker MM. Investigation into the toxicological effects of Catha edulis leaves: a short term study in animals. Phyther Res. 2002:16(2):127-32.

38. Al-Hashem FH, Bin-Jaliah I, Dallak MA, Nwoye LO, Al-Khateeb M, Sakr HF, et al. Khat (Catha edulis) extract increases oxidative stress parameters and impairs renal and hepatic functions in rats. Bahrain Med Bull. 2011;33(1):32.

39. Kilkenny C, Browne W, Cuthill I, Emerson M, Altman D. Improving bioscience research reporting: The ARRIVE guidelines for reporting animal research. J Pharmacol Pharmacother. 2010;1(2):94-9.

\section{Publisher's Note}

Springer Nature remains neutral with regard to jurisdictional claims in published maps and institutional affiliations. 